\title{
Pelatihan dan pendampingan pengelolaan web profile SMPN 1 Kalibening
}

\author{
Ari Kusuma Wardana, ${ }^{1, *}$, Rianto $^{2}$, Ekha Rifki Fauzi ${ }^{3}$ \\ ${ }^{1,2}$ Program Studi Informatika, Fakultas Sains dan Teknologi, Universitas PGRI Yogyakarta \\ ${ }^{3}$ Teknologi Rekayasa Elektromedis, Fakultas Sains dan Teknologi, Universitas PGRI Yogyakarta \\ Email Korespondensi:*ari@upy.ac.id
}

Received May 24, 2021; Revised June 30, 2021; Accepted August 23, 2021

\begin{abstract}
Abstrak
Teknologi bekembang begitu pesat, salah satu bagian dari perkembangan teknologi yaitu website. Kehadiran website profile suatu organisasi, company atau lembaga di era digital sekarang ini menjadi kebutuhan yang wajib untuk dimiliki. SMP Negeri 1 Kalibening merupakan salah satu sekolah terbesar di lingkungan kecamatan Kalibening. SMP Negeri 1 Kalibening belum memiliki web profile, dimana dengan web profile dapat memperkenalkan dan memberikan informasi mengenai profile sekolah kepada pihak lain yang membutuhkan, baik itu peserta didik, calon peserta didik, orang tua peserta didik, maupun sekolah tetangga. Adanya permasalahan tersebut maka pelatihan dan pendampingan pengelolaan web profile sekolah menjadi masalah yang penting dan perlu di ditindaklajuti untuk memudahkan pihak SMP untuk mengisi dan mengelola konten di dalam web. Sehingga informasi yang ada di web selalu terbaru dan kebenarannya bisa dipercaya. Dengan adanya pelatihan dan pendampingan ini, SMP Negeri 1 Kalibening sudah bisa memiliki web profile seperti sekolah-sekolah lain dan dan mengelola konten-konten yang akan dimuat di dalam website dengan baik dan benar. Selain itu, dapat memajukan sekolah karena dengan adanya web profile sekolah, masyarakat sekitar dapat memperoleh informasi mengenai sekolah secara cepat dan mudah.
\end{abstract}

Kata Kunci: web profil; web konten; smp

Abstract
Technology is developing so rapidly, one part of technological development, namely the website. The presence of a website profile of an organization, company, or institution in today's digital era is a must-have. SMP Negeri 1 Kalibening is one of the largest schools in the Kalibening sub-district. SMP Negeri 1 Kalibening does not yet have a web profile, where a web profile can introduce and provide information about the school profile to other parties who need it, be it students, prospective students, parents of students, or neighboring schools. With these problems, training and assistance in managing school web profiles is an important problem and needs to be followed up to make it easier for junior high schools to fill in and manage content on the web. So that the information on the web is always up to date and the truth can be trusted. With this training and mentoring, SMP Negeri 1 Kalibening has been able to have a web profile like other schools and manage the content that will be posted on the website properly and correctly. In addition, it can advance the school because, with the school's web profile, the surrounding community can get information about the school quickly and easily.

Keywords : web profi; web content; smp

\section{PENDAHULUAN}

Sistem informasi tersusun secara prosedur, terorganisir dan sistematis, pada saat dijalankan akan menghasilkan suatu informasi yang berguna dan bermanfaat bagi organisasi mencapai tujuan[1]. Penyebaran informasi melalui internet menjadi gaya hidup bagi sebagian besar masyarakat, apalagi ditambah dengan penemuan virus Covid-19 yang mewabah sejak akhir 2019[2], hampir banyak sektor beralih kegiatan yang terfokus dengan internet.

Internet tidak hanya diakses melalu perangkat berupa komputer, tetapi sudah beralih ke perangkat yang lebih kecil seperti smartphone[3]. Selain berisi berbagai macam informasi, internet juga dapat digunakan untuk meningkatkan kegiatan promosi[4] dengan biaya yang murah dan terjangkau[5]. Maka dalam hal ini web sangat penting untuk mengenalkan diri kepada masyarakat umum. Website dapat diartikan sebagai kumpulan halamanhalaman yang digunakan untuk menampilkan informasi teks, gambar, animasi, suara dan atau gabungan dari semuanya, baik brsifat statis maupun dinamis[6].

Hal ini menjadikan website sangat penting, apalagi untuk lembaga pendidikan seperti sekolah-sekolah. Selain itu pemanfaatan media sosial juga sangat mendukung untuk pemasaran[7] branding dari sekolah. Tetapi dengan penggunaan web akan lebih menyakinkan, selain itu tanpa mengenal batasan-batasan yang dimiliki oleh 
media sosial. Menggunakan web akan dapat memberikan informasi lebih luas kepada peserta didik, calon peserta didik, orang tua peserta didik, maupun sekolah tetangga.

SMP Negeri 1 Kalibening merupakan sekolah menengah pertama di wilayah kecamatan kalibening, kabupaten Banjarnegara, provinsi Jawa Tengah. SMP Negeri 1 SMP Negeri 1 Kalibening menjadi salah satu SMP Favorite untuk investasi pendidikan jangka panjang[8], sehingga hasilnya tidak dapat dilihat dan dirasakan secara instan. Sebagai sekolah favorit untuk masyarakat diwilayah kecamatan Kalibening, maka dalam perkembangan teknologi ini, SMP Negeri 1 Kalibening membutuhkan web dimana pada kenyataanya SMP Negeri 1 Kalibening belum memiliki web. Hal ini dibutuhkan untuk penyebaran informasi terkait sekolah. Akan tetapi, web juga membutuhkan pengelolaan dari isi web supaya konten akan disampaikan menarik dan dapat diterima oleh masyarakat umum, dengan hal ini maka pelatihan dan pendampingan pengelolaan web sangat dibutuhkan.

Membangun sebuah halaman website untuk masa saat ini sangatlah mudah, banyak sekali teknik yang bisa digunakan. CMS menjadi salah satu pilihan tanpa melibatkan webmaster[9]. Akan tetapi tidak menutup kemungkinan juga membangun website dengan menggunakan bahasa pemograman PHP, sehingga kerahasiaan dari kode-kode dapat dijaga kerahasiaanya[10].

Berdasarkan permasalahan tersebut maka solusi yang tepat yaitu dengan mengadakan pengabdian di SMP Negeri 1 Kalibening. Adapun pengabdian yang dilakukan adalah membuatkan sebuah web untuk sekolah tersebut serta memberikan pelatihan dan pendampingan dalam mengelola web beserta konten-konten yang ada di dalamnya. Harapannya adalah dengan adanya pengabdian ini, SMP Negeri 1 Kalibening sudah bisa memiliki web seperti sekolah lain yang sudah terlebih dahulu memiliki web dan dapat memanfaatkan web yang dimiliki dengan maksimal. Selain itu, dengan pengabdian ini dapat memajukan sekolah karena dengan adanya web sekolah, masyarakat sekitar dapat memperoleh informasi mengenai sekolah secara cepat dan mudah.

\section{METODE}

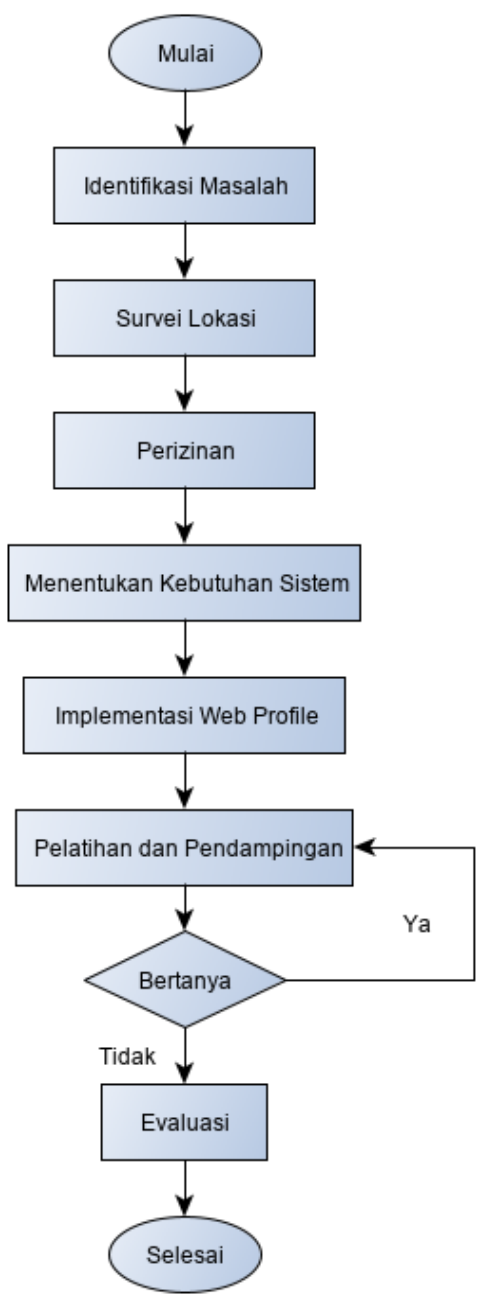

Gambar 1. Metode Pelaksanaan 
Pada gambar 1 adalah metode pelaksanaan pengabdian dari mulai sampai dengan selesai. Pengabdian dimulai dengan terlebih dahulu melakukan observasi dan wawancara secara tidak langsung di SMP Negeri 1 Kalibening, wawancara dilakukan yang dilakukan bertujuan untuk mengidentifikasi masalah yang berada di tempat tersebut. Setelah pengidentifikasian masalah yang dihadapi SMP Negeri 1 Kalibening maka tahap berikutnya dengan melakukan survey ke lokasi pengabidan. Kebutuhan terkait perijinan dan dilakukan seiring dengan mengumpulan kebutuhan data dan kriteria-kriteria yang dibutuhkan dalam membuat web profile. Selain survei serta pelatihan dan pendampingan, semua di lakukan secara daring karena karena adanya pandemi COVID-19. Dari observasi yang dilakukan di SMP Negeri 1 Kalibening maka diperoleh analisa SWOT yang dapat dilihat pada tabel 1 .

Tabel 1. Analisa SWOT

\begin{tabular}{ll}
\hline SWOT & \multicolumn{1}{c}{ Keterangan } \\
\hline Kekuatan (Strengths) & Website merupakan salah satu media promosi untuk menarik \\
& siswa. \\
& Pengelola website merupakan guru dan staff lab komputer, \\
& sehingga memudahkan dalam proses pelatihan. \\
Kelemahan (Weaknesses) & Jaringan internet sudah terdapat di SMP Negeri 1 Kalibening. \\
& SMP Negeri 1 Kalibening belum mempunyai website \\
& sekolah. \\
& Pengenalan SMP yang masih dilakukan dari mulut ke mulut. \\
& Terdapat banyak keunggulan sekolah yang belum diketahui \\
& oleh calon siswa. \\
Peluang (Opportunities) & SMP Negeri 1 Kalibening merupakan salah satu SMP \\
& favorite di wilayah Banjarnegara. \\
- & Keinginan guru-guru yang ingin memiliki web profile \\
& sekolah untuk mengenalkan fasilitas sekolah yang dimiliki. \\
Ancaman (Threats) & Telah banyak sekolah-sekolah lain yang telah memiliki \\
& website sekolah. \\
\hline
\end{tabular}

Dari analisa SWOT pada tabel 1, maka upaya dalam kepemilikan website sekolah dan pelatihan dalam mengelola website menjadi sangat penting untuk mendukung proses pengenalan sekolah khususnya SMP Negeri 1 Kalibening. Adapun hal yang harus dilakukan dalam yaitu dengan membuatkan sebuah website sekolah terlebih dahulu, sesuai dengan kebutuhan sekolah kemudian dilanjutkan dengan melakukan pelatihan terhadap guru yang akan mengelola website tersebut. Pada metode pelatihan dilaksanaan sebanyak 4 kali pertemuan dimana tiap pertemuan dilakukan selama 2 jam. Evaluasi nantiknya akan dilakukan, agar kedepannya kegiatan pengabdian kepada masyarakat jauh lebih baik dari yang sebelumnya. Adapun metode pelaksanaan pengabdian meliputi beberapa komponen yang dapat dilihat pada tabel 2 .

Tabel 2. Komponen dalam pelaksanaan kegiatan pengabdian masyarakat

\begin{tabular}{ll}
\hline Komponen & Keterangan \\
\hline SDM (Sumber daya Manusia) & Pada pelaksanaan pengabdian ini dilakukan secara tatap muka \\
dan secara daring yang diikuti oleh 10 peserta dari guru-guru di \\
SMP Negeri 1 Kalibening, dimana pelatihan yang diberikan \\
berupa pengelolaan web profil sekolah yang sebelumnya sudah \\
dibuat oleh panitia pengabdi sesuai dengan kebutuhan sekolah \\
tersebut. \\
Proses pelaksanaan pada pengabdian ini dilakukan secara tatap \\
muka dan secara daring dengan total pertemuan sebanyak 4 kali \\
pertemuan dengan waktu pelakasanaan selama 2 jam. \\
Pertemuan pertama: pada pertemuan pertama dilakukan secara \\
tatap muka, hal ini dilakukan untuk menghindari ketidaktahuan \\
atau kebingungan peserta pelatihan saat pertama kali melakukan \\
pelatihan pengelolaan website. Pada pertemuan pertama ini \\
peserta pelatihan memperoleh materi berupa cara mengakses \\
halaman utama dan halaman admin serta mengelola halaman \\
pengguna bagi admin. \\
Pertemuan kedua: pada pertemuan kedua dilakukan sedara daring \\
dengan melalui aplikasi zoom meeting. Pada pertemuan ini \\
peserta pelatihan memperoleh materi berupa pengelolaan gambar \\
pada halaman home website SMP Negeri 1 Kalibening,
\end{tabular}


Produk

pengelolaan data guru dan pengelolaan data siswa.

Pertemuan ketiga: pada pertemuan ketiga dilakukan secara daring dengan melalui aplikasi zoom meeting. Pada pertemuan ini peserta pelatihan memperoleh materi berupa pengelolaan halaman blog, pengelolaan halaman pengumuman, pengelolaan agenda dan pengelolaan halaman download.

Pertemuan keempat: pada pertemuan ketiga dilakukan secara daring dengan melalui aplikasi zoom meeting. Pada pertemuan ini peserta pelatihan memperoleh materi berupa pengelolaan halaman gallery, pengelolaan halaman kontak dan pengelolaan halaman komentar.

Hasil yang diperoleh pada pelatihan ini berupa halaman profile website SMP Negeri 1 Kalibening, dimana pada pelatihan ini peserta hanya memperoleh pelatihan dan pendampingan dalam pengelolaan halaman website untuk profil SMP Negeri 1 Kalibening. Produk ini telah dibuat sebelumnya oleh panitia pelaksanaan pengabdian yang mana produk ini dibuat sesuai dengan kebutuhan untuk menyelesaikan masalah yang di hadapi oleh SMP Negeri 1 Kalibening yaitu tidak memiliki web profile untuk dijadikan salah satu faktor dalam kegiatan promosi.

Ketiga komponen tersebut sangat penting dalam proses pelaksanaan kegiatan pengabdian kepada masyarakat dimana hasil dari kegiatan tersebut akan dilakukan evaluasi untuk meningkatkan kualiats pengabdian yang akan dilakukan berikutnya.

\section{HASIL DAN PEMBAHASAN}

Perencanaan pada kegiatan ini telah dimulai sejak bulan Februari 2021, dimana kegiatan ini sebelumnya telah dikomunikasikan dengan Kepala Sekolah SMP Negeri 1 Kalibening Banjarnegara. Akan tetapi pelaksanaan kegiatan ini baru dimulai pada awal bulan April 2021. Kegiatan pengabdian ini dilakukan di SMP Negeri 1 Kalibening yang terletak di utara Kota Kecamatan Kalibening sebagai pusat kota. Didirikan di atas tanah yang strategis di tengah-tengah wilayah kecamatan yang mudah dijangkau dari semua lokasi, dengan alamat di Jl. Catur Marga, Kelurahan Kalibening, Kecamatan Kalibening, Kabupaten Banjarnegara, Kode Pos 53458. Jarak yang ditempuh dari tempat pengabdi ke lokasi pengabdian sekitar $150 \mathrm{KM}$ dengan waktu tempuh sekitar 3 jam 45 menit. Adapun jarak lokasi pengabdian dapat dilihat pada gambar 2.
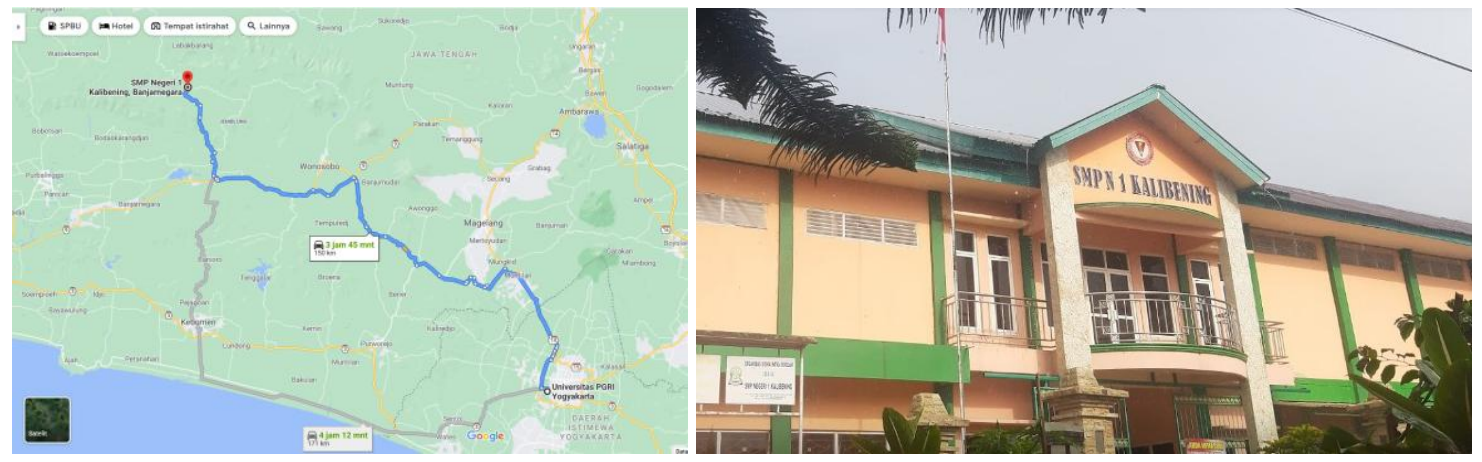

Gambar 2. Lokasi pengabdian

Pada pelatihan ini diikuti oleh 10 peserta yang dilakukan secara tatap muka dan secara daring, dimana peserta dari pelatihan ini merupakan guru-guru dari SMP Negeri 1 Kalibening. Adapun kegiatan yang dilakukan berupa pelatihan ini berupa pengelolaan halaman website yang sebelumnya telah di buat oleh pengabdi. Adapun halaman website yang telah dibuat untuk pelatihan pengabdian ini dapat dilihat pada gambar 3. 


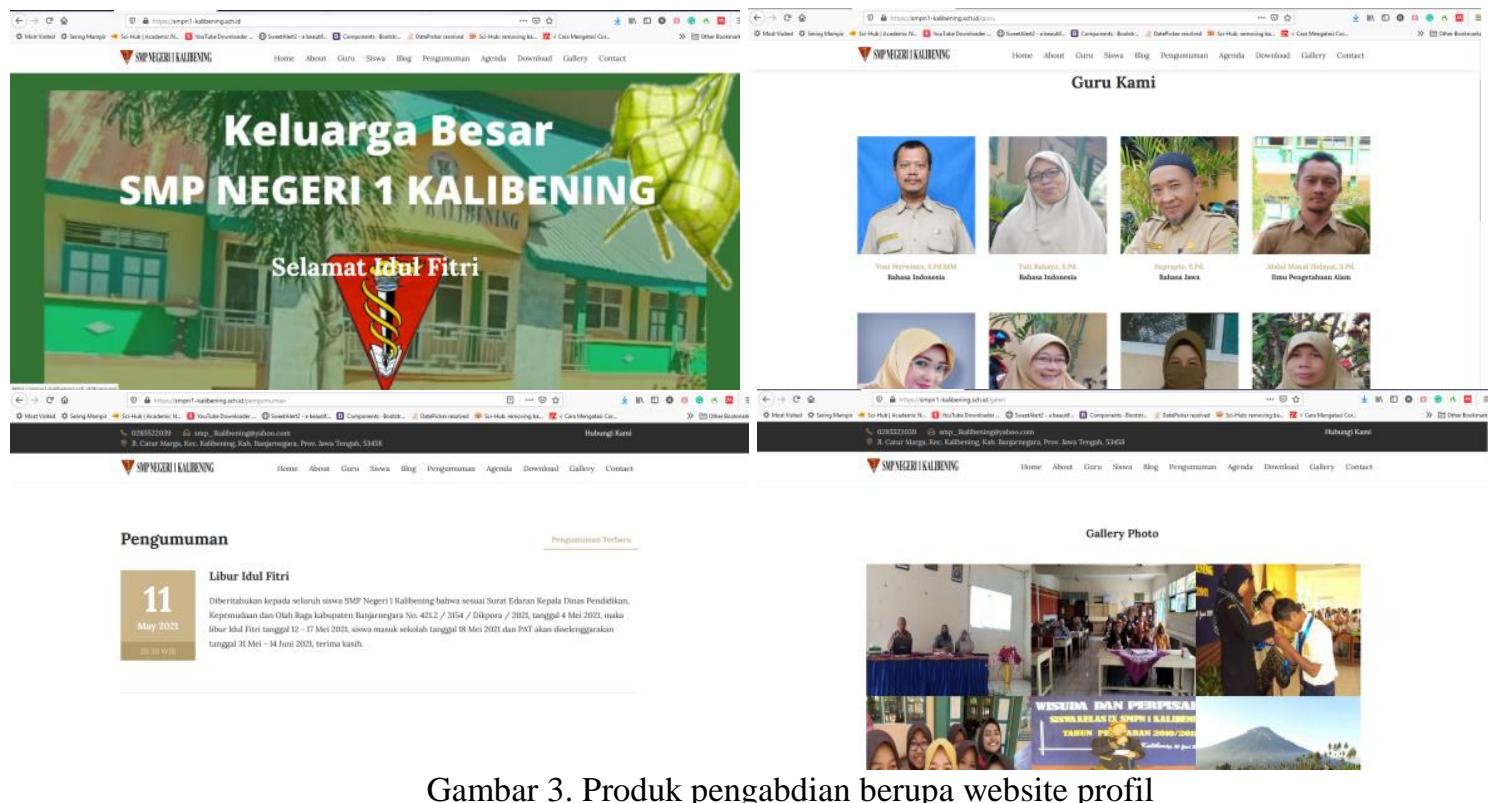

Pelatihan pada pertemuan pertama dengan mengenalkan website profile yang telah dibuat untuk SMP Negeri 1 Kalibening. Pada pertemuan ini mengenalkan komponen-komponen yang terdapat pada website sebelum memasuki praktek dalam pengelolaan halaman website. Setelah peserta memahami dan mengetahui komponen-komponen yang terdapat dalam website tersebut, maka peserta pelatihan mendapatkan materi pelatihan berupa cara mengakses halaman utama dan halaman admin serta mengelola halaman pengguna bagi admin. Pada pelatihan ini dilakukan secara tatap muka yang dilaksakan selama 2 jam. Proses pelaksanaan kegiatan ini dapat dilihat pada gambar 4.

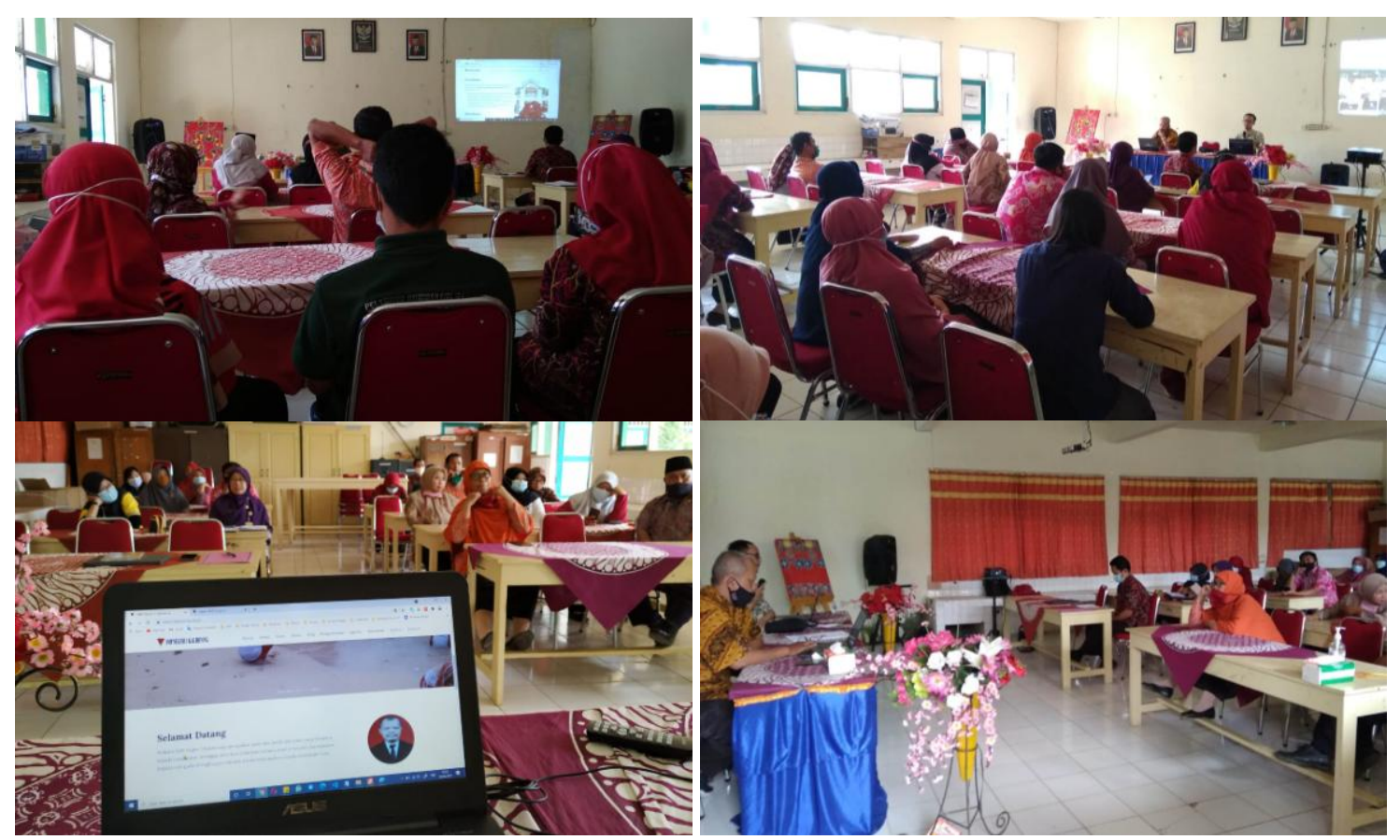

Gambar 4. Pelaksanaan pelatihan pengelolaan website profil secara tatap muka

Pelaksanaan pelatihan hari kedua, ketiga dan keempat dilakukan secara daring dengan menggunakan aplikasi zoom meeting. Materi yang disampikan pada pertemuan ini adalah pengelolaan gambar pada halaman home website SMP Negeri 1 Kalibening, pengelolaan data guru dan pengelolaan data siswa, pengelolaan halaman blog, pengelolaan halaman pengumuman, pengelolaan agenda dan pengelolaan halaman download, pengelolaan halaman gallery, pengelolaan halaman kontak dan pengelolaan halaman komentar. Kegiatan pelatihan yang dilakukan secara daring dapat dilihat pada gambar 4 . 

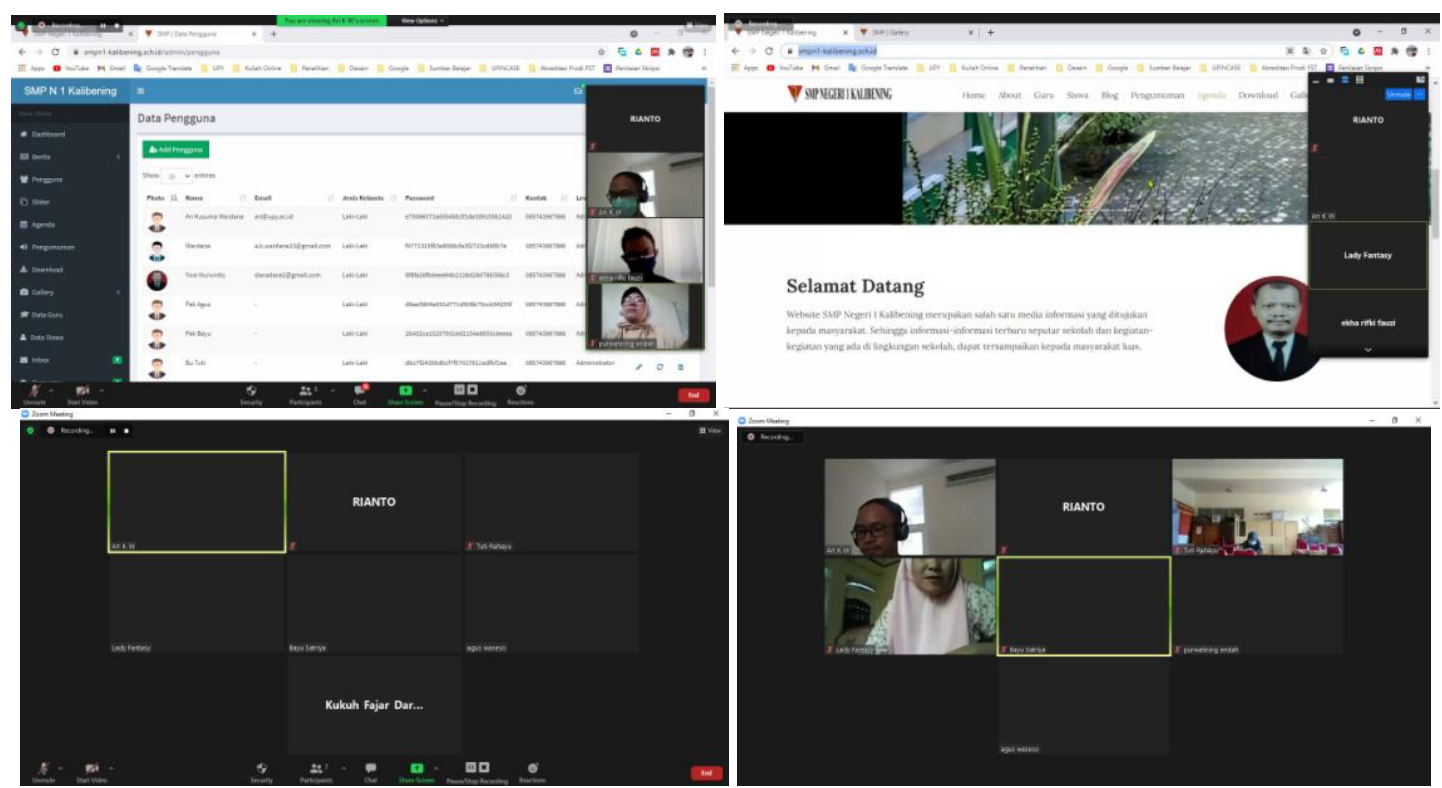

Gambar 5. Pelaksanaan pelatihan pengelolaan website profil secara daring

Kendala yang dihadapi saat pelatihan ini adalah pada metode yang digunaakan saat pelaksanaan yang dilakukan secara daring. Interaksi tidak dapat dilaksanakan secara langsung apabila ada peserta yang ingin bertanya mengenai kendala yang di hadapi saat melakukan proses pelatihan. Selain itu jaringan menjadi salah satu permasalahan yang dihadapi oleh peserta, karena jaringan internet yang dimiliki oleh peserta pelatihan yang tidak stabil.

Setiap peserta mempunyai usia dan ketrampilan yang bervariasi, dari usia yang lebih muda lebih mudah memahami materi yang disampaikan, akan tetapi kembali lagi dari ketrampilan dari peserta pelatihan. Peserta pelatihan yang mengajar komputer lebih cakap dalam mengoperasikan komputer dan memahami materi tersebut. Di sisi lain masih dibutuhkan pendampingan secara intens untuk pengelolaan web tersebut.

Penilaian keberhasilan dari pelatihan ini dilihat dengan melalui survey dengan menggunakan tiga komponen yaitu pemahaman materi, manfaat produk dan penyampaian materi. Hasil dari penilaian tersebut dapat dilihat pada gambar 6.

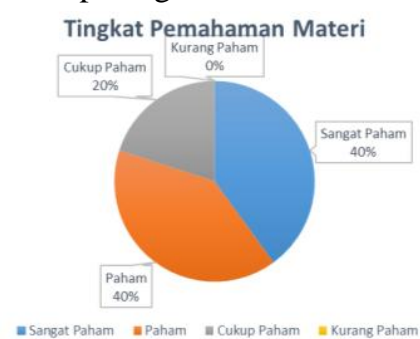

(a)

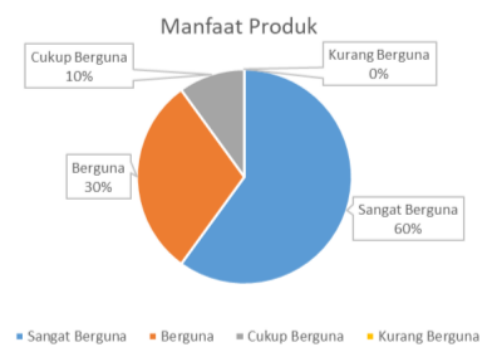

(b)

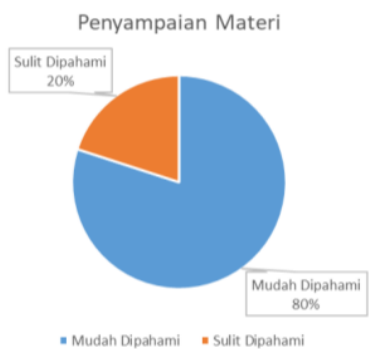

(c)

Gambar 6. Survey hasil pelatihan (a) Tingkat pemahaman, (b) Manfaat produk dan

(c) Penyampaian materi

Berdasarkan gambar 5 dapat dilihat bahwa tingkat keberhasilan dari pelatihan ini sudah cukup memuaskan, dimana pada tingkat pemahaman peserta dalam memahmi materi sebagai $40 \%$ peserta sangat memahami dengan materi yang disampaikan, $40 \%$ peserta lagi paham dan hanya $20 \%$ peserta yang cukup paham dengan materi tersebut. Sedangkan kemanfaatan produk dari materi yang diajarkan menilai bahwa produk tersebut sangat berguna yaitu sebesar $60 \%$. Sedangkan cara penyampaian materi sebanyak 80 peserta benar-benar dengan mudah dalam mamahami penyampaian materi tersebut, sedangkan $20 \%$ sulit memamahami. Dari beberapa hasil survey tersebut, maka pelatihan ini dapat disimpulkan berhasil, meskipun ada beberapa dari peserta perlu dilakukan pendampingan khusus.

\section{KESIMPULAN}

Kegiatan pelatihan dan pendampingan dalam mengelola web profile kepada guru-guru di SMP N 1 Kalibening dapat memberikan dampak positif dalam pengembangan teknologi, walaupun pada dasarnya pelatihan dan pendampingan ini dikhususkan pada pengelola web profil SMP N 1 Kalibening. Dengan adanya pelatihan dan pendampingan ini guru-guru dapat mengerti dan membahami bahwa untuk mengelola web profil 
bukan berate mempelajari script bahasa pemograman yang digunakan untuk web profile tersebut. Dengan pelatihan dan pendampingan tersebut guru dapat melakukan update konten-konten yang berupa gambar, tabel, video, teks dengan menggunakan menu admin yang telah dibuat sebelumnya oleh tim pengabdi. Pada awalnya peserta mengira dalam mengelola web profil adalah sesuatu yang sangat sulit, akan tetapi setelah pelatihan ini perserta sudah mulai beranggapan bahwa mengelola web profil tidak sesulit seperti yang dibayangkan. Setelah SMP N 1 Kalibening memiliki web profil harapan kedepannya dapat semakin dikenal oleh masyarakat baik di wilayah kalibening maupun tingkat nasional, bahwa SMP N 1 Kalibening adalah sekolah favorite dengan memiliki fasilitas dan kualitas yang lebih dalam dunia pendidikan. Saran berkelanjutan dari kegiatan ini harapannya, web benar-benar dapat dikelola sehingga benar-benar menjadi sarana promosi bagi sekolah. Selain itu web juga dapat dikembangkan menjadi sebuah sistem informasi yang komunikatif antara sekolah dan pengguna.

\section{DAFTAR PUSTAKA}

[1] N. Nurmi, "Membangun Website Sistem Informasi Dinas Pariwisata," Edik Inform., vol. 1, no. 2, pp. 1-6, 2017.

[2] M. H. Barri, A. Rizal, W. A. Cahyadi, I. Hidayat, B. A. Pramudita, and N. Prihatiningrum, "Pelatihan ECommerce Bagi Warung Sedekah (Warkah) Untuk Meningkatkan Pertumbuhan Ekonomi Rumah Tangga," KACANEGARA J. Pengabdi. pada Masy., vol. 4, no. 1, p. 83, 2021.

[3] D. Pranata, H. Hamdani, and D. M. Khairina, "Rancang Bangun Website Jurnal Ilmiah Bidang Komputer (Studi Kasus : Program Studi Ilmu Komputer Universitas Mulawarman)," Inform. Mulawarman J. Ilm. Ilmu Komput., vol. 10, no. 2, p. 25, 2015.

[4] M. Susilo, "Rancang Bangun Website Toko Online Menggunakan Metode Waterfall," InfoTekJar (Jurnal Nas. Inform. dan Teknol. Jaringan), vol. 2, no. 2, pp. 98-105, 2018.

[5] H. Heldiansyah and R. Indera, "Pengembangan Sistem Informasi Penjualan Alat Kesehatan Berbasis Web Pada PT. Alfin Fanca Prima," Positif, vol. 1, no. 1, 2015.

[6] R. Hidayat, Cara praktis membangun website gratis. Yogyakarta: Elex Media Komputindo, 2010.

[7] R. Retnowati, E. N. Wahyudi, S. N. Anwar, and H. Listiyono, "Optimalisasi Media Sosial Facebook Untuk Mendukung Perluasan Jaringan Pemasaran Bagi Kelompok Wanita Kreatif (Kwk) Seroja," KACANEGARA J. Pengabdi. pada Masy., vol. 4, no. 1, p. 1, 2021.

[8] D. W. Santoso, "Pengenalan Penggunaan Software Perancangan," KACANEGARA J. Pengabdi. pada Masy., vol. 2, no. 1, pp. 55-59, 2019.

[9] Husni, Pemrograman database berbasis web, 1st ed. Yogyakarta: Graha Ilmu, 2007.

[10] A. Kadir, Pemrograman Web mencakup $=$ HTML, CSS Javascript \& PHP Abdul Kadir. Yogyakarta: Andi Offset, 2003. 
